\author{
Violetta BEDNARSKA ${ }^{1}$ \\ Henryka CZYŻ ${ }^{2}$ \\ Tadeusz JASIŃSKI ${ }^{3}$
}

\title{
ADVANCES IN HEARING PROSTHETICS
}

\begin{abstract}
This text analyses several topics connected with hearing test methods and hearing prosthetics for patients with hearing impairments or hearing loss. The hearing is one of the senses which plays a crucial part in human's cognition of the surrounding world and spatial orientation. Proper functioning of the hearing organ is a foundation of communication between people as well as the development of civil society. A hearing impairment or hearing loss disrupts social relationships between people, it entails developmental disorders in children, and causes learning difficulties. Methods of diagnosing patients and hearing prosthetics are very complex topics and are investigated by interdisciplinary research teams. The development of these fields of medicine and technology contributes to improving the quality of life for people with hearing impairment or deafness. This paper presents ways and means of improving or compensating for hearing losses with the use of hearing aids. Nowadays, hearing impairments and hearing losses concern even young people. One of the reasons for the deterioration of hearing is the ubiquitous noise in the modern world. Moreover, this text discusses the construction of hearing aids, with a particular emphasis placed on modern technological solutions. It is highlighted that hearing aids are currently available for the general public.
\end{abstract}

Keywords: auditory perception, hearing test methods, hearing aids

\section{INTRODUCTION}

Hearing is one of the long-range senses. It is crucial in order for humans to be able to receive information about the external world, and to orientate themselves in space. The hearing organ receives stimuli without our conscious knowledge - it is even active when we are sleeping. The human ear is a system that detects the direction, volume, pitch and timbre of sound. A diagram of the construction of the human ear is shown in Fig. 1.

1 Corresponding author: Violetta Bednarska, Rzeszow University of Technology, Powstańców Warszawy 12, 35-959 Rzeszów, e-mail: v.bednarska@prz.edu.pl

2 Henryka Czyż, Rzeszow University of Technology, e-mail: hczyz@ prz.edu.pl

3 Tadeusz Jasiński, Rzeszow University of Technology, e-mail: jasinski@prz.edu.pl 


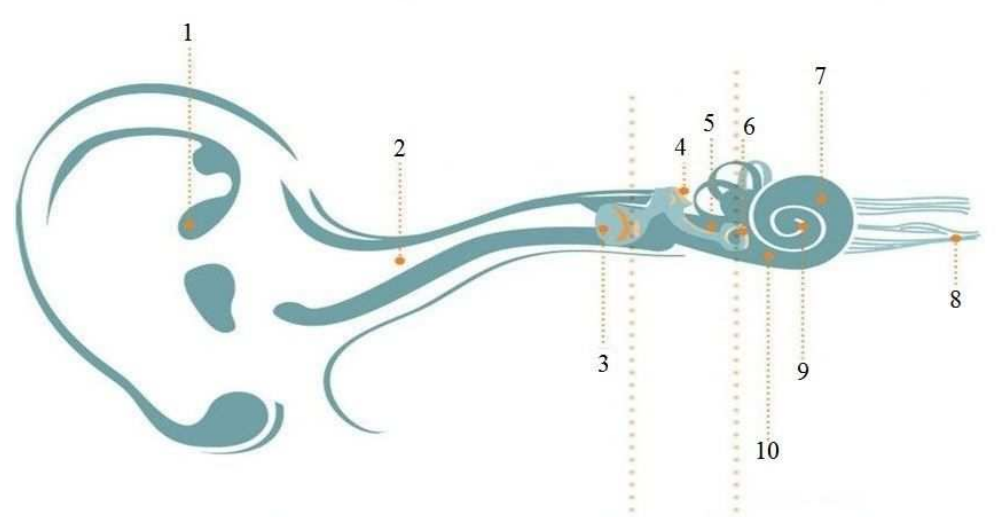

Fig. 1. The hearing organ. Outer ear: 1 - Pinna, 2 - Auditory Canal, 3 - Tympanic membrane. Middle ear: 4 - Malleus, 5 - Incus, 6 - Stapes. Inner ear: 7 - Cochlea, 8 - Cochlear nerve, 9 - Vestibule, 10 - Round window

Hearing is said to be the most important social sense. Its impairment or loss affects social interaction $[1,2]$.

Depending on the patient age, hearing loss may cause developmental deficits (in children) or learning difficulties, or may simply prevent the affected individual from functioning in a world where communication is based on sounds. Therefore, considerable attention is paid to hearing prosthetics which can restore hearing even to a large extent, depending on the degree of hearing loss and the applicable prosthetics.

Hearing disorders may be due to a variety of hearing defects. Consequently, the location of the hearing problem is a key element in choosing a suitable hearing aid.

Depending on whether interaction with the patient during a hearing test is necessary or not, the types of hearing tests can be divided into subjective (psychophysical) tests, in which the patient's active participation is essential, and objective (electrophysiological) tests, in which no active cooperation between the patient and the testing person is required [3].

\section{SUBJECTIVE HEARING TESTS}

\subsection{Psychophysical tests}

The most common subjective hearing tests include:

- speech audiometry,

- behavioural observation audiometry,

- pure tone audiometry [4]. 
Irrespective of the hearing test to be subsequently applied, the first diagnostic step should be to take the patient's medical history. It aims to identify the patient's problems, as well as the sound environment they live in and the level of hearing improvement they expect.

\subsection{Speech audiometry - distance test}

This test method is used to assess hearing acuity and hearing loss. Hearing acuity defines the greatest distance from which speech is clearly heard and exactly repeated by the patient. It is expressed in metres or centimetres.

Such a hearing test based on natural speech does not allow determination of the location of hearing loss in the auditory pathway; it only makes it possible to determine whether a given patient has a hearing problem [3].

\section{Weber test}

This test allows for a determination of the type of hearing loss - it makes it possible to determine whether the patient's hearing is asymmetric or symmetric (Table 1). Symmetric hearing means that the hearing loss is of the same type and degree in both ears. If sound is heard only in in one ear, then the patient hearing is asymmetric.

Table 1. Patient cases of hearing loss

\begin{tabular}{|l|c|}
\hline Sound is heard everywhere in the head & Symmetric hearing \\
\hline Sound is heard in the middle of the head & Symmetric hearing \\
\hline Sound is heard on the left & Asymmetric hearing \\
\hline Sound is heard on the right & Asymmetric hearing \\
\hline
\end{tabular}

\section{Rinne test}

The Rinne test is performed separately for each ear. Based on the length of time the patient can hear the tuning fork, it is possible to determine the type of hearing loss in the ear tested.

\section{Schwabach test}

The Schwabach test is based on comparing bone conduction in the patient and that in the examiner (with an assumption that the examiner has normal hearing). The test is performed separately for each ear. The type of hearing loss can be determined by comparing the lengths of time the patient and the examiner can hear the bone-conducted sound.

\section{Bing test}

This test is based on an assessment of the occlusion effect in an occluded ear. It is performed separately for each ear, with the use of tuning forks. It is used to test absolute and relative bone conduction of sound. If the result of this test is 
positive, then the patient's hearing is normal or there is sensorineural hearing loss in the ear tested. If the Bing test yields a negative result, then the patient's hearing loss is conductive hearing loss.

\section{Lewis-Federici test}

This test is performed using a tuning fork. If the test yields a physiological result, the patient has normal hearing or sensorineural hearing loss. If the test result is pathological, the patient has conductive hearing loss.

\section{Gellé test}

This test helps to confirm, in the case of a pathological result to the LewisFereici test, that the patient has conductive hearing loss.

\subsection{Audiometers}

Audiometric tests are performed using an audiometer that generates auditory stimuli consisting of sine waves and noise [5].

An audiometer is a measuring device designed to evaluate hearing acuity using pure tone or speech signals. It is built of a system setting signal intensity, a signal generator producing tones and noise of different frequencies and volumes, air and bone conduction headphones and a loudspeaker emitting such signals. Audiometers can be broken down by the type of emitted signals, the type of signal presentation and by functions, hearing levels and frequencies.

The aim of an audiometric test is to determine the degree of hearing loss. Threshold tests are performed to determine the patient threshold of hearing. The audible thresholds are presented as a broken line in an audiogram. The line connects dots representing hearing levels for the particular frequencies expressed in dB HL (decibels Hearing Level ).

Audiometric tests require a conscious response to auditory stimuli from the patient.

\subsection{Methods for measuring auditory thresholds}

Auditory threshold measurements for air and bone conduction differ due to the difference in the two conduction mechanisms. Supra-threshold tests are for the purpose of assessing the impact of supra-threshold stimuli (i.e. stimuli above $0 \mathrm{~dB}$ SL (decibels Sensation Level)) on the organ of hearing (Table 2).

Supra-threshold tests also allow the determination of the precise location of damage to the auditory pathway. There are four types of supra-threshold tests, namely:

- loudness compensation,

- intensity differentiation,

- adaptation and auditory fatigue,

- hearing in noise. 
Intensity differentiation tests, adaptation tests, auditory fatigue tests and hearing in noise tests (HINTs) are also used to measure hearing loss.

Table 2. Sound assessment scale

\begin{tabular}{|l|c|}
\hline \multicolumn{1}{|c|}{ Sound reception } & $\begin{array}{c}\text { Value } \\
{[\mathbf{d B} \text { SL] }}\end{array}$ \\
\hline No sound heard & 0 \\
\hline Very quiet & $1-11$ \\
\hline Quiet & $11-20$ \\
\hline Moderately loud (well heard) & $21-30$ \\
\hline Loud & $31-40$ \\
\hline Very loud & $41-50$ \\
\hline Too loud & $>50$ \\
\hline
\end{tabular}

\section{OBJECTIVE HEARING TESTS}

\subsection{Impedance audiometry}

Impedance audiometry is a simple, non-invasive and automated method for hearing assessment. The test takes no more than a few minutes. The test result is not influenced by the attitude of the patient or by their level of cooperation, so this method is very useful in measuring children's hearing. It is also the most widespread among apparatus-based methods, and the measuring devices used in this method are part of the basic equipment of every audiology room [6].

The parameter tested is the acoustic impedance of the middle ear. It is the resistance put up by the sound conduction system (tympanic membrane, three auditory ossicles and ligaments in the tympanic cavity) to acoustic waves. The most common impedance values for a normally hearing ear range between 1000 and 3000 acoustic ohms.

Most modern audiometric devices are based on the reciprocal of acoustic impedance, that is, acoustic admittance. Admittance can be defined as the ease of acoustic energy flow through the vibrating system of the middle ear. The unit of admittance is $1 / \mathrm{ohm}$.

Tests using impedance audiometry help to detect various conditions of the middle ear and the state of the connections between its components.

Impedance audiometry refers to several tests which allow:

- calculation of the acoustic impedance value for the ear,

- testing of the motor function of the facial nerve,

- assessment of patency of the Eustachian tube,

- determination of the acoustic reflex threshold,

- differentiation between cochlear and retrocochlear hearing losses based on the stapedius reflex. 


\subsection{Tympanometry}

Tympanometry is a measurement of pressure in the middle ear. The impedance of the middle ear is measured using the so-called impedance bridge [7]. In such a measurement, air pressure in the external auditory canal is changed from negative to positive and, at the same time, a test tone of a specific frequency is generated - this is the measurement of the system compliance. The compliance is the ability of the ear structures to stretch when exposed to various factors. Modern tympanometric devices automatically calculate the middle ear compliance [8]. The tympanometry result in the form of a tympanometric curve provides information about possible defects in the sound conduction system. Depending on the tympanogram type, the distinctive shape of the curve may, for example, indicate exudative otitis media, Eustachian tube dysfunctions or atrophic scars in the tympanic membrane etc. [8].

\subsection{Stapedius reflex}

The stapedius reflex, also known as the acoustic reflex, occurs in people with normal hearing and is absent in deaf people [9]. It is triggered by a high-intensity sound stimulus in the transversely striated muscles and is one of the bilateral reflexes (activation of one side with a strong stimulus triggers a binaural reflex). It is a defense reflex - it protects the inner ear against loud sounds and Corti's organ against damage.

The aim of the acoustic reflex test is to test the reflex and to determine the lowest intensity of an acoustic stimulus that will decrease the compliance of the middle ear. Absence of the reflex may indicate conductive or perceptive hearing loss.

\subsection{Otoacoustic emission}

The phenomenon of OAE (otoacoustic emission) was discovered in 1976 [10]. The emission is a reaction of auditory hair cells to a sound stimulus. When sounds are heard, the sensory cells of the cochlea act as an amplifier, contracting and relaxing. The cochlea is the place where an otoacoustic emission is generated. An echo comes from various cochlear processes and is associated with the contraction of the outer hair cells. When the sound heard is pleasing, the brain "orders" the cochlea to make it louder, and, in contrast, when the sound is received with reluctance, the cochlear has to make it softer. A part of the sound comes back to the ear. It can then be measured and the hearing quality can be assessed.

An otoacoustic emission is a faint sound generated from within the inner ear and emitted to the external auditory canal.

OAEs are among the objective and non-invasive methods for the assessment of the cochlear micromechanics. OAEs allow assessment of the inner ear function 
and detection of disturbances in sensory cells. This method is used to test for hyperacusis and to detect hearing losses caused by pharmaceutical agents. The phenomenon of otoacoustic emissions is present in all subjects, even in newborns.

\section{Spontaneous otoacoustic emission (SOAE)}

A spontaneous otoacoustic emission (SOAE) is a sound emitted from the ear spontaneously, without external acoustic stimulation. Its clinical application is limited. It is not observed in all subjects with normal hearing and is therefore not commonly used to diagnose hearing impairment.

\section{Evoked otoacoustic emission (EOAE)}

An evoked otoacoustic emission (EOAE) is one of the most valuable methods to test hearing. It is observed in all or almost all healthy ears. Such an emission is a response from the cochlea to an auditory stimulus emitted to the outer ear. We can distinguish between several types of EOAEs which differ in the stimulus produced.

Evoked otoacoustic emissions are used in a wide variety of clinical applications. With them it is possible to:

- perform screenings for potential hearing loss,

- monitor hearing impairments resulting from exposure to noise,

- monitor ototoxicity of drugs

- detect functional deafness

- diagnose tinnitus

- monitor the cochlear functions during neurootological operations.

\section{Auditory evoked potentials}

Auditory evoked potentials (AEPs) are of great importance in the diagnosis of hearing disorders [6]. These techniques measure an expression of the electrical activity in certain sections of the auditory pathway.

We can distinguish between potentials generated in:

- the cochlea,

- the vestibulocochlear nerve,

- the brain stem,

- subcortical centres and the cerebral cortex.

AEPs are critical in the diagnosis of hearing impairment in babies and newborns. They allow early detection of retrocochlear disorders and are used to assess hearing sensitivity, to make differential diagnostics and to intraoperatively monitor the electrical activity of the auditory system. The evoked potential method is shown schematically in Fig. 2. 


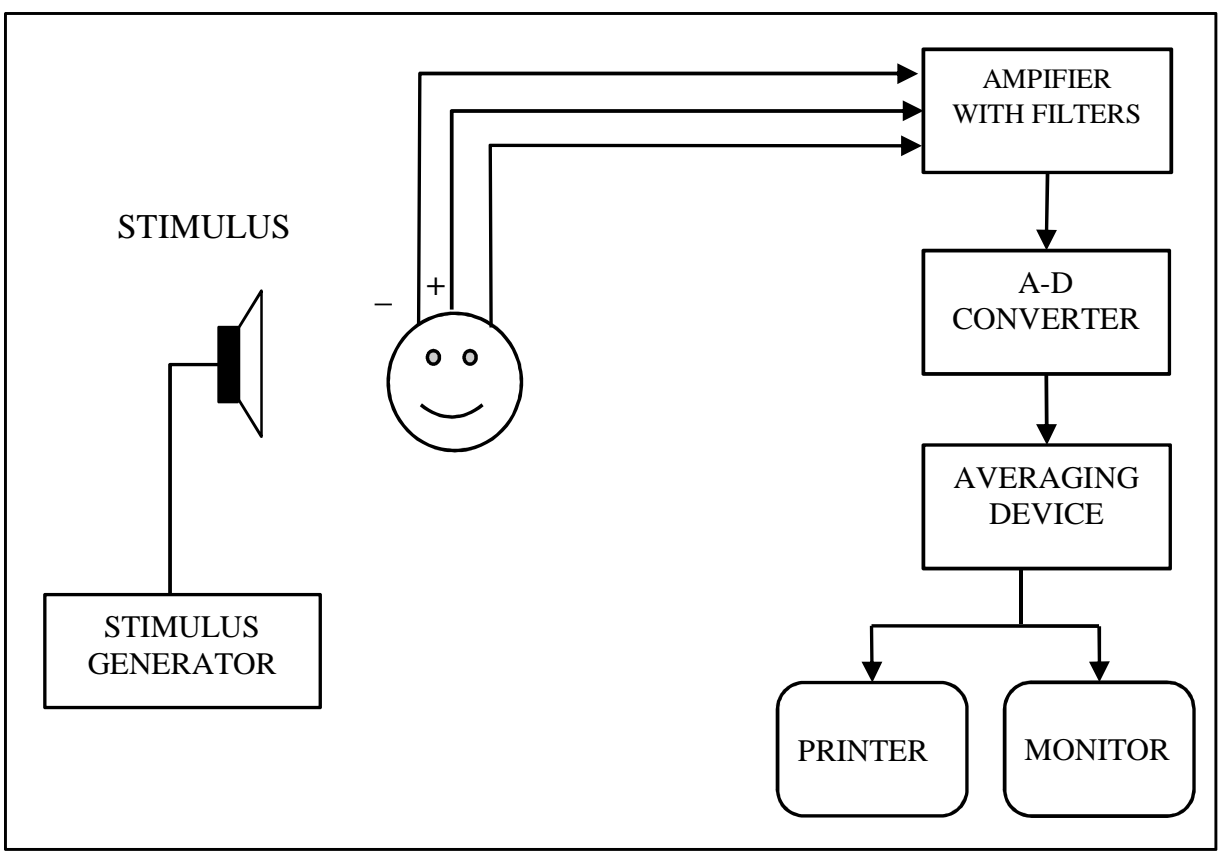

Fig. 2. The apparatus set used for recording auditory evoked potentials. +, - electrodes

\subsection{Types of auditory evoked potentials}

\section{Electrocochleography}

Electrocochleography (ECOG) is a hearing test which consists in measuring electrical potentials generated in the middle ear in response to sound stimulation. ECOG is not very useful in clinical practice because an electrode must be placed in the tympanic cavity or in the auditory canal. Electrocochleography is seen as an invasive method. It is applied only when auditory neuropathy or Ménière's disease is suspected.

\section{Brainstem auditory evoked potentials}

Brainstem auditory evoked potentials (BAEPs) are used to [8]:

- determine audible thresholds,

- perform screenings for potential hearing loss in newborns,

- perform differential diagnostics of hearing disorders,

- monitor the function of the brain stem and the vestibulocochlear nerve during otoneurosurgical procedures.

This test is performed to examine patients of all ages, including adults and babies. 
BAEPs are often used to diagnose retrocochlear hearing disorders. In this test, response to a click is recorded separately for each ear and then the parameters are compared to each other and to normal ranges.

\section{Middle latency responses (MLR)}

MLR can be used to assess auditory thresholds, especially for low frequencies which are difficult to assess by other methods.

\section{Mismatch negativity (MMN)}

Auditory mismatch negativity (MMN), or long-latency auditory evoked potentials should be the cerebral cortex's automatic response involving detection of a lack of compliance between the features of the frequent stimulus and those of the rare stimulus. The MMN method can be applied in research on sound recognition and perception processes as well as in examinations of patients with disorders relating to the central process of auditory information processing.

\section{Auditory steady state response (ASSR)}

Auditory steady state response (ASSR) is linked to middle latency responses. ASSRs are analysed using modern statistical methods. The ASSR method can have applications in determining the auditory threshold in normally hearing and hearing-impaired individuals. The use of continuous stimuli makes it possible to record responses from both persons with hearing aids and those with cochlear implants. This allows an objective assessment of the effectiveness of the process of choosing hearing aids or implants for children.

\section{CORE COMPONENTS AND CLASSIFICATION OF HEARING AIDS}

\subsection{Diagram of a hearing aid}

A block diagram of a hearing aid [6] is shown in Figure 3.

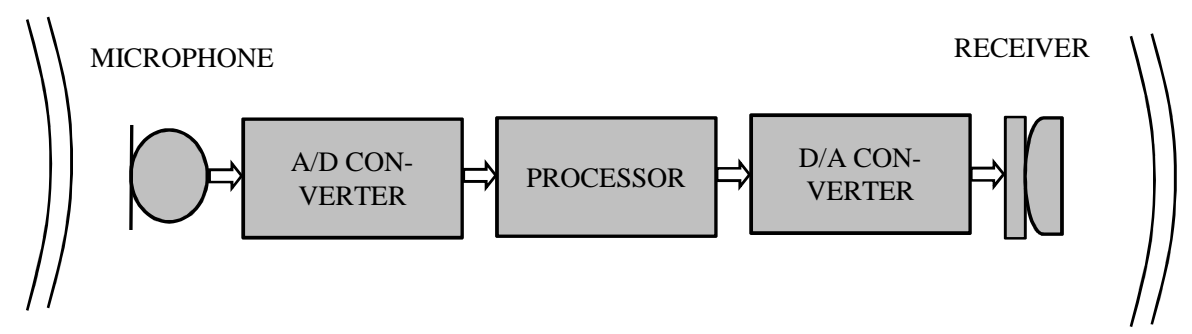

Fig. 3. A block diagram of the digital processing path in a hearing aid 


\section{Microphone}

In hearing aids, the microphone is responsible for converting an acoustic signal into an electrical signal which is then processed by the hearing aid processing systems. The electrical signal must be as close as possible to the acoustic input signal of the hearing aid.

The use of several microphones in one hearing aid means that they must be miniaturized whilst maintaining similar acoustic parameters. The introduction of MEMS (microelectromechanical systems) technology enables construction of microphones with considerably smaller sizes than those existing to date.

\section{Amplifiers}

An amplifier is used to increase the value of the electrical signal from the microphone (accordingly for the particular frequency bands required and dependent on the patient's hearing loss). The amplifier makes the sound, the level of which is lower than the hearing-impaired individual threshold of hearing, audible to the individual.

\section{Compression systems}

Compression systems are used to limit the output signal of the hearing aid and to adjust the acoustic signal dynamics of the hearing aid microphone to the auditory dynamics of the hearing-impaired individual.

\section{Filters}

Hearing aid filters are systems that allow the shaping of the frequency characteristic in the hearing aid receiver.

Distinctions are made between:

- high-pass filters that allow higher signal amplification for higher frequencies,

- low-pass filters that allow ensuring higher amplification for lower frequencies,

- band-pass filters that pass components of the acoustic signal for a specific frequency range - between the lower and the upper cut-off frequencies,

- band-elimination filters that pass components of the acoustic signal which are present outside a specific frequency range [6].

Filters are applied in hearing aids for shaping the amplification characteristic within a wide frequency range. The frequency characteristic includes specific resonances - sudden signal escalations by even several decibels for narrow frequency bands. This has an adverse effect on the hearing aid's frequency characteristic. The main reason for these resonances to occur is, more than anything else, the system characterised by a specific resonance frequency dependent on the sizes of the said components.

The resonances make speech less clear, cause difficulty in identifying sounds and reduce the quality of the sound transmitted by the hearing aid. Variously 
shaped silencers, made from different materials, depending on the hearing aid parameters, are used to eliminate the resonances in the frequency characteristic.

\section{Digital system}

The digital technology applied in hearing aids allows them to more effectively process the acoustic signal because the digital signal processor:

- compresses and amplifies the signal (in accordance with the perception models for a given pathology and those for normal hearing),

- performs spatial filtering and reduces disturbing noises and acoustic feedback (separately for the useful signal and for the noisy signal), etc.

The system uses specialist algorithms responsible for storing specific setting parameters in the hearing aid (which depend on the degree and type of hearing loss and on the patient's perceptual habits). The settings are selected automatically in accordance with the acoustic conditions of a given environment [11].

\subsection{Sampling and quantization}

A process in which a discrete value is attributed to each and every value within the time of the signal amplitude component and in which a numerical quantity is attributed to discrete components is called signal quantization. This process is completed by an analog-to-digital converter ( $\mathrm{a} / \mathrm{d}$ converter). Quantization, sampling and processing of a digital-analog signal involves the risk of a specific error.

It is possible to minimize such errors by starting a series of procedures for the sampling, processing, and quantizing of the signal.

Speech signal components (vowels and consonants) are sensitive to quantization errors. Vowels are more sensitive than consonants. For vowels, an individual with normal hearing will notice differences in the auditory perception when the resolution of the converter is transformed by 3 bits, whereas for consonants, differences are noticeable when the resolution is changed by 10 bits. This is due to the easier detection of the disturbances occurring in the harmonic structure of vowels.

People with normal hearing demonstrated the same understanding of speech, when the signal was quantized with either an 8-bit converter or a 16-bit converter (an 8-bit converter is characterised by signal dynamics of $48 \mathrm{~dB}$, whereas a 16-bit converter by dynamics of $96 \mathrm{~dB}$ ). When using a hearing aid with a converter with a degree of quantization above 12 bits, they described the speech signal as "noisy". Typically, the use of analog-to-digital converters with a resolution above 8 bits guarantees that the reception of the quantization noise will fade out.

In digital hearing aids, the components that may contribute to delay distortions are the microphone and the receiver, both of which are analog components. Given their physico-material and geometric parameters, it can be speculated that the distortions caused by them are very slight. 


\section{Receivers}

Most hearing aids feature an electromagnetic receiver. Its operating principle is identical with that of a dynamic loudspeaker: changes in the current flowing through the coil in the speaker cause changes in the magnetic field it generates. In turn a permanent magnet is inside this magnetic field connected to a membrane. The changing magnetic field causes it to move, setting the membrane in motion. The membrane forces air particles to move and the result is an acoustic wave.

In the hearing aid receiver, the membrane's motion is made by a small circuit system that connects the variable magnetic field (generated by the coil) to the fixed magnetic field generated by the magnet.

Hearing aid receivers, just as hearing aid microphones, should feature a frequency characteristic that ensures good transmission of the "speech banana". It is equally important that this characteristic is relatively flat and devoid of distinct extrema. The structure of the entire electromechanical system contributes to the occurrence of such extrema. The extrema are a result of magnetic resonance of the membrane and of resonance of the air inside the receiver. A lack of evenness in the frequency characteristic can be compensated by various solutions, such as acoustic and electric filters [6].

\section{Powering hearing aids}

Powering electronic hearing aids has always been, and still is, an important issue.. A hearing aid should work continuously and for as long as possible. This determines the necessary properties of the power supply. The hearing aid parameters should not vary over time. It is therefore necessary to use a stable source of energy. Electric cells, or batteries, have been used in hearing aids as a source of energy for many years. Today, electric cells enable operation of a hearing aid for as long as 2 weeks.

Accumulators are also used in hearing aids (mainly in first class devices) however they work for a considerably shorter time than batteries. The positive point of this solution is the possibility of making the hearing aid smaller. The negative points are the relatively high manufacturing cost of such an energy source, and its short working time after recharging. This solution therefore requires frequent access to an external electricity supply.

\subsection{Classification of hearing aids}

Hearing aids can be divided up into a number of types [12]. The simplest division is that according to their structure. It is directly associated with the device sizes.

- Pocket devices are the biggest hearing aids .

- Behind-the-ear (BTE) hearing aids are most popular. 
Another group is made up of hearing aids inserted in the ear canal. All the hearing aid components are enclosed in the housing that is individually moulded to fit the patient ear.

- In-the-ear (ITE) hearing aids are custom-made to fit completely in the patient ear, i.e. in the concha (cavum and cymba).

- In-the-canal (ITC) hearing aids are smaller than in-the-ear hearing aids and are partly visible in the concha.

- Completely-in-the-canal (CIC) hearing aids are virtually invisible in the patient ear.

Hearing aids that are directly inserted in the patient ear canal are hardly visible and, compared to other hearing aid types, ensure the best location of sound sources (when inserted, the microphone is inside the external auditory canal). The drawbacks of such hearing aids are their high susceptibility to acoustic feedback (due to the short distance between the microphone and the receiver), exposure to dampness (a risk of damage to the hearing aid) and more difficult volume control (due to the small size).

An eyeglass hearing aid is a combination of hearing aids and glasses. The eyeglass rims have in-built BTE hearing aids [6].

\section{MODERN TECHNOLOGICAL SOLUTIONS FOR HEARING AIDS}

\subsection{Elimination of acoustic feedback}

The following non-exhaustive list of systems designed to prevent generation of redundant signals can be applied to reduce acoustic feedback [13 ]:

- tight ear moulds,

- reduction of amplification within the set frequency range in which the feedback arises,

- smaller ventilating holes in the ear mould or use of a closed ear mould,

- narrow-band filters (so-called notch filters).

Currently, the most effective feedback reduction system is one that uses the anaphase signal. The system monitors the hearing aid's output by detecting feedback with a distinctive frequency and generates a signal with the same amplitude and frequency but in opposite phase. This results in complete disappearance of the component responsible for the generation of acoustic feedback. The application of this system allows additional amplification of the signal by a few decibels.

\subsection{Compression systems}

Automatic gain control, or a compression system, is a system in which an increase in the input signal amplitude results in automatic reduction of amplification of the hearing aid's output signal. 
There are two basic types of compression system:

- on-input compression system $\left(\mathrm{AGC}_{1}\right)$ which adjusts the dynamics of the acoustic input signal of the hearing aid to the dynamics of the field of hearing remnants in the hearing-impaired individual,

- on-output compression system $\left(\mathrm{AGC}_{0}\right)$ which reduces the pressure level of the output signal of the hearing aid.

Hearing aids should be fit to the individual and their settings should be later corrected so as to meet the patient needs which may depend on the acoustic environment they live in. This is facilitated by the following systems: Datalogging, and Ddatalearning.

\section{Datalogging, datalearning}

The Ddatalearning and datalogging functions are used in a number of hearing aid types by different manufacturers [3].

The data storage function, or datalogging, stores the data containing the hearing aid user's preferences during everyday use, such as:

- the length of time of remaining in an acoustic environment,

- the type of the environment in which the hearing aid user stayed (speech without background noise, in noise, music, etc.),

- the duration of wearing the hearing aid,

- the preferences as to the use of different hearing programmes.

The information collected during the use of the hearing aid, can be added to the data received by interviewing the patient, and be used by a hearing aid professional at the time of the correction of the hearing aid settings [14 ]. The data help to correct the hearing programme settings entered by a hearing aid professional and to establish the optimal amplification during the next visits of the user to the hearing care centre. A hearing aid featuring automatic environment classification can activate the programme set for a specific situation [ 15 ].

The datalearning function offers automatic optimization of the hearing aid settings and additional training for the user.

\section{SUMMARY AND CONCLUSIONS}

The human process of hearing sounds, the types of hearing loss or impairment, the diagnostic methods for hearing impairment, and hearing prosthetics together make up a very complex issue. Today, multidisciplinary research teams are involved in testing and preventing hearing loss, as well as in the fitting of hearing aids. The development of these fields of medicine and technology results in the improvement in the quality of life of people in an ageing society.

The World Health Organisation has set 3rd March as the International Ear Care Day in order to draw the public's attention to issues relating to ear conditions, hearing loss, and hearing impairment. Hearing loss is often a chronic disability 
even in young people. Causes of hearing loss include the noise surrounding us in the modern world.

Modern, technologically advanced, hearing aids are now widely available to the general population.

\section{REFERENCES}

[1] Hoffmann B. Surdopedagogika, PWN, Warszawa 1987.

[2] Pickles J.O., An introduction to the physiology of hearing, Academic Press, Berkeley 1988.

[3] Hojan E., Dopasowanie aparatów stuchowych, Mediton, Łódź 2009.

[4] Hojan E. Protetyka stuchu, Wydawnictwo Naukowe UAM, Poznań 2016.

[5] Grzesik J., Bodźce akustyczne, PWN, Warszawa 1977.

[6] Kochanek K. Audiofonologia, Wydawnictwo Polski Komitet Audiofonologii, 1999.

[7] Schuster K., Eine Methode zum vergleich akustischer impedanzen, Phys Zeitschrift 1934, 35, p. 408. Terkildsen K. ,Thomsen K.A., The influence of pressure variations on the impedance of the human eardrum, J Laryngol. Otol., 1959, 73, p. 409.

[8] Śliwińska-Kowalska M., Audiologia kliniczna, Mediton, Łódź 2005.

[9] Sęk A.P., Percepcja dźwięku, Forum Psychologiczne, 2000, 5, 1, pp. 5-26.

[10] Kemp D.T., Stimulated acoustic emission from within the human auditory system, J Acoust Soc Am, 1978, 64, pp. 1386-1391.

[11] Hojan E. Akustyka aparatów stuchowych, Wydawnictwo Naukowe UAM, Poznań 1997.

[12] Dillon H., Hearing aids, Boomerang Press, Sydney 2012.

[13] Valente M. (editor), Hearing aids: Standards options and limitations, Thieme, New York 1996.

[14] Valente M., Strategies for selecting and verifying hearing aid fittings, Thieme, New York 2002.

[15] Woźniak M., CROS type hearing aids, Specialist Seminar, Listening protection, Wydawnictwo Naukowe UAM, Poznań 2009.

\section{POSTEPY W PROTETYCE SLUCHU}

W pracy dokonano analizy zagadnień związanych z metodami badania i protetyki słuchu pacjentów z niedosłuchem i ubytkiem słuchu. Słuch jest jednym z receptorów, który odgrywa u człowieka ważną rolę w poznawaniu otaczającego świata i orientacji w przestrzeni. Prawidłowe funkcjonowanie narządu słuchu stanowi podstawę komunikacji między ludźmi i rozwoju społeczeństwa. Uszkodzenie lub utrata słuchu zaburza relacje społeczne między ludźmi, powoduje zaburzenia rozwoju u dzieci oraz trudności w nauce. Metody diagnozowania pacjentów i protetyka słuchu stanowią bardzo złożone zagadnienia, którymi zajmują się interdyscyplinarne zespoły badawcze. Rozwój tych dziedzin medycyny i techniki przyczynia się do poprawy jakości życia osób z niedosłuchem lub głuchotą. Przedstawiono w pracy sposoby i możliwości poprawy lub kompensacji ubytków słuchu za pomocą aparatów słuchowych. Wady i ubytki słuchu dotyczą obecnie nawet młodych ludzi. Jedną z przyczyn pogorszenia się słuchu u człowieka jest otaczający nas we współczesnym świecie hałas. Zaprezentowano też w pracy budowę aparatu słuchowego, ze szczególnym uwzględnieniem 
nowoczesnych rozwiązań technologicznych. Podkreślono, że aparaty słuchowe są obecnie dostępne dla ogółu społeczeństwa.

Słowa kluczowe: percepcja dźwięku, metody badania słuchu, aparaty słuchowe

DOI: 10.7862/rf.2018.pfe.1

Received 12.04.2018

Accepted 7.05.2018 